\title{
Diversity of trees, mollusks and birds associated to agricultural land uses in Nicaragua
}

\author{
A. Mijail Pérez, Marlon Sotelo \& Isabel Siria \\ Gaia Association, Colonia 10 de Junio, B-501, Managua, Nicaragua, Tel. 505- 2249 3127.; mijail64@gmail.com
}

Received 19-VIII-2013 • Corrected 17-I-2014 • Accepted 9-II-2014

\begin{abstract}
An important effect of cattle raising in Nicaragua has been the fragmentation of natural landscapes, mainly forests. In the present paper we analyze species composition and community structure for birds, mollusks and trees in several silvopastoral systems and land uses in Matiguás and Paiwas, Matagalpa, Nicaragua. We also studied the relationship between vegetation structure and mollusks and birds as biological indicators. Within the study landscapes 45 out of 212 observed bird species and 16 out of 56 observed mollusk species were uniquely associated to a single land use. Beta diversity could be considered mediumis intermediate for both taxa (ca. 0,5), in a scale ranging from 0 to 1. The observed avifauna across all land uses included 119 generalists $(56,1 \%), 26$ forest-dependent species $(12,26 \%)$ and 67 open-area species $(31,6 \%)$, based on the forest dependence categories of Stiles and Skutch. Mollusk species composition included: 33 forest-dependent species (59\%), 20 generalists species (35,7\%), and 3 open-area species $(5,36 \%)$. We observed significant correlations between species diversity of trees and structural diversity of trees $(r=0,88, p<0,01)$ and between structural diversity of trees and species diversity of mollusks as well as species richness of mollusks $(r=0,655, p<0,05$, and $r=0,7, p<$ 0,01 , respectively). Results also indicate the existence of a significant correlation between Vegetation Species Richness and Bird Diversity $(r=0,7, p<0,05)$. There were no correlations between Bird Diversity and Vegetation Diversity, or between Bird Diversity and Structural Diversity. Silvopastoral systems contain highly diverse communities of animals and plants that should be managed properly on the landscape context in order to create a matrix where conservation and rural livelihoods can coexist.
\end{abstract}

KEY WORDS: Diversity, Trees, Mollusks, Birds, Agricultural Land Uses, Nicaragua.

\section{RESUMEN}

Un efecto importante de la ganadería en Nicaragua ha sido la fragmentación de los paisajes naturales, principalmente bosques. En el presente trabajo se analiza la composición de especies y la estructura de las comunidades de aves, moluscos y árboles presentes en diferentes sistemas silvopastoriles o usos de suelo de Matiguás y Paiwas, Dpto. de Matagalpa, Nicaragua. También se estudió la relación entre los moluscos y aves como indicadores biológicos y la estructura de la vegetación. En el estudio de paisajes 45 de las 212 especies de aves observadas y 16 de las 56 especies de moluscos observadas se relacionaron exclusivamente a un solo uso de la tierra. La diversidad beta podría ser considerada media para ambos taxones (ca. 0,5$)$, en una escala que va de 0 a 1. La avifauna observada a través de todos los usos del suelo incluye 26 especies dependientes de los bosques (12,26\%), 119 generalistas $(56,1 \%)$, y 67 especies de zonas abiertas $(31,6 \%)$, con base en las categorías de dependencia del bosque de Stiles y Skutch. La composición de especies de moluscos incluyó: 33 especies dependientes de los bosques (59\%), 20 especies generalistas (35,7\%), así como 3 especies de zonas abiertas (5,36\%). Se observó una correlación significativa entre la diversidad de especies de árboles y la diversidad estructural de los árboles $(r=0,88, p<0,01)$, y entre la diversidad estructural de los árboles y la diversidad de especies de moluscos, así como con la riqueza de especies de moluscos $(r=0,655, p<0,05, y r=0,7, p<0,01$, respectivamente). Los resultados también indican la existencia de una correlación significativa entre la riqueza de especies de la vegetación y la diversidad de las aves $(r=0.7, p<0.05)$, sin embargo la relación entre la diversidad de aves y la diversidad de la vegetación, así como la diversidad de aves y la diversidad estructural fueron no significativas. Nuestro estudio muestra que los sistemas silvopastoriles contienen comunidades con una alta diversidad de animales y plantas que deben ser manejados adecuadamente en el contexto del paisaje para crear una matriz donde la conservación y la producción puedan coexistir.

PALABRAS CLAVES: Diversidad, árboles, moluscos, aves, usos de suelo agrícola, Nicaragua. 
An important effect of cattle raising in Nicaragua has been fragmentation of natural landscapes, mainly forests. In the central region and elsewhere, fragmentation has resulted from deforestation to exploit local forest resources and to create new areas for farming and cattle raising (Levard, Marín \& Navarro, 2001; Ruíz, 2003). In the case of Nicaragua the high percentage of land dedicated to agriculture, is considered a $37,49 \%$ of the country $\left(48875,00 \mathrm{Km}^{2}\right.$ of the country's area) (MARENA, 2004).

Deforestation has affected important ecological processes including dispersion, migration, and competition, resulting in local species extinction and decreased biodiversity at a landscape level (Harris, 1984; Wilcox, 1980). The remaining forest cover of the country estimated by the national forest inventory is of $3254145 \mathrm{Ha}$ (= $32541,45 \mathrm{Km}^{2}$ ), representing $25 \%$ of the land territory of Nicaragua (INAFOR, 2009).

Studying components of each particular system in the context of the landscape will approach the optimal way to handle them, and fortunately there is increasing diversity data from different biological groups in fragmented ecosystems and silvopastoral systems in particular that can be used as bioindicators (Petit \& Usher, 1998; Bergin, Best, Freemark \& Koehler, 2000; Fournier \& Loreau, 2001; Ricketts, Daily, Ehrlich \& Pay, 2001; Estrada \& CoatesEstrada, 2002; Pérez, 2002; Jeanneret, Schüpbach, Pfiffner \& Walter, 2003; Weibull, Ostman \& Granquist, 2003; Naranjo, 2004).

However, as pointed out by Schulze et al. (2004), most studies have quantified the anthropogenic impact on the diversity of a single taxonomic group, with exceptions such as the work done by the same authors, which included plants, birds and insects, the one by Lawton et al. (1998) that included several groups, the contribution of Kessler, Herzog, Fjeld and Back (2001), who studied plants and birds and the papers by Pérez et al. (2004a), Pérez, Sotelo, Ramírez, Ramírez, López and Siria (2006) and more recently González-Valdivia et al. (2011) which considered plants, birds and landsnails, and the latter which studied as well butterflies.

There are also important data on plants in general, hedgerows, bats, birds and dung beetles that have generated several publications (Cárdenas, Harvey, Ibrahim \& Finnegan, 2003; Hernández et al., 2003; Lang, Lorraine, Harvey \& Sinclair, 2003; Villanueva, Ibrahim, Harvey \& Esquivel, 2003; López, Gómez, Harvey \& Villanueva, 2004; Medina, Harvey, Vílchez, Sánchez \& Hernández, 2004; Sánchez et al., 2004; Vílchez, Harvey, Sánchez, Medina \& Hernández, 2004; Vílchez et al., 2008;). It should be noted that most published data refer to studies related to birds, dung beetles and plants, while apparently the first published data on mollusks in agro-forestry-pastoral systems are those of Perez et al. (2004a). There is also a work of great interest concerning the use of ants as indicators in agro-ecosystems and also a literature revision on that subject (Luna, 2005).

In the present paper we present results of various analyses regarding community structure on bird and mollusk communities, as well as analyses on vegetation structure's variables. We also analyzed the relation of species richness and diversity of indicators with measured vegetation structure's variables on different agricultural land uses in Matiguás and Paiwas, Dpt. of Matagalpa, each of which reflects a different agricultural management strategy.

These results allowed us to propose management and conservation priorities at a local level, as well as enhancing the importance of silvopastoral systems as biodiversity reservoirs outside protected areas. The latter is a widely discussed issue among the Nicaraguan and the Central American scientific community, particularly in the context of efforts to implementing the Mesoamerican Biological Corridor (CBM-MARENA, 2001), a regional initiative that seeks to conserve biodiversity and increase habitat connectivity throughout Mesoamerica while supporting sustainable agriculture, forestry, and rural livelihoods.

We studied three taxa representing different levels of mobility or vagility that fauna displays in the response to changing conditions (Wilcox, Murphy, Ehrlich \& Austin, 1986): invertebrates with low mobility (mollusks), vertebrates with very high mobility (birds), and trees (sessile).

\section{MATERIALS AND METHODS}

Study site: The study site was located in the Department of Matagalpa in north-central Nicaragua within the triangle bounded by the protected areas of Sierra Quirragua to the West, Cerro Musún to the North, and Fila Masigüe to the South (Fig. 1). The site encompassed two non-contiguous areas: 1) the Comarca of Bulbul within the Town of Matiguás (UTM 670165 E, $1417108 \mathrm{~N}$ ), containing $1335 \mathrm{~km}^{2}$ and a population of 38584 inhabitants, of which $81 \%$ live on rural areas (INEC, 1995; Agostini, Ibrahim, Murgueitio \& Ramirez, 2003); as well as the Comarca of Paiwas, belonging to the Town of Río Blanco, with coordinates UTM 686152 $\mathrm{E}, 1424706 \mathrm{~N}$, an extension of $700 \mathrm{~km}^{2}$ and a population of 33195 inhabitants of which 23950 (72,15\%) live on rural areas (Agostini et al., 2003); both zones belong to the Department (= province) of Matagalpa, which is one of the 15 Departments the country is divided into, 


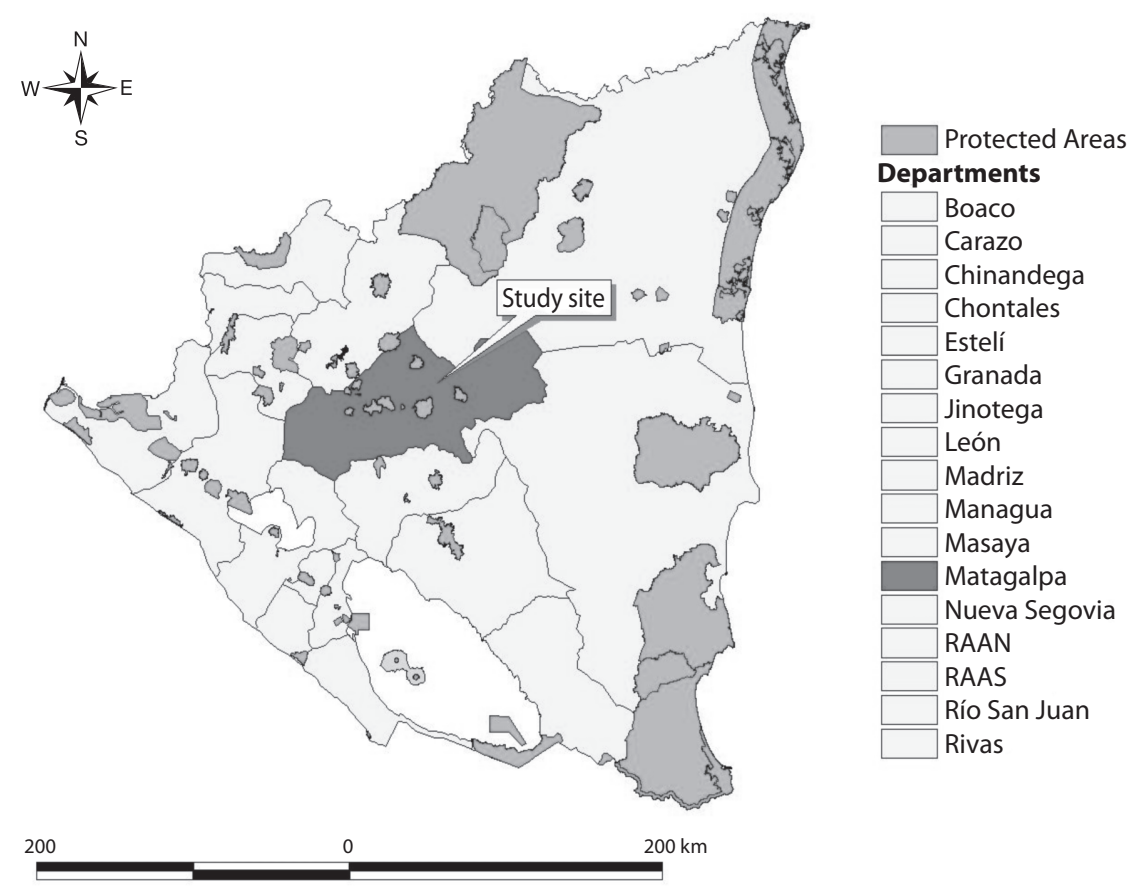

Fig. 1. Study site located within the triangle composed of the protected areas of Sierra Quirragua, Cerro Musún and Fila Masigüe to the south. Elaboration: Antonio Mijail Pérez, Map information on Protected Areas taken from the Ministry of Environment (MARENA).

as well as two autonomous regions (North Atlantic and South Atlantic).

Selection of farms and land-use types: We chose 12 land use types that we considered representative of Nicaraguan cattle farms land-uses, plus a nearby protected area for comparison. Land uses included natural pasture with high tree density (PNA), natural pasture with low tree density (PNB), improved pasture with high tree density (PMA), improved pasture with low tree density $(\mathrm{PMB})$, pasture without trees (PNS), fodder bank (BFL), live fence $(C P)$, successional vegetation (SV), riparian forest (BR), modified secondary forest (BSI), secondary forest (BS), primary forest (BP), and primary forest of the Quirragua protected area ( $\mathrm{BPQ}=\mathrm{BPP})$. A description of land uses can be found in (INIFOM, 2004).

We made a non-random first level of selection of our sampling farms. We chose farms with as many land use types as possible in order to minimize travel time among farms. From the first group, we selected farms with land uses exceeding 0,7 ha to ensure that sampling quadrants would be able to fit within land use plots.

For vegetation and bird sampling we selected ten quadrants per land use type whenever possible, following the Rule of 10 (Gotelli \& Ellison, 2004). No more than one quadrant was surveyed per land use type per farm. To minimize the possibility of edge effect in our surveys, we situated the centre of the sampling quadrant approximately at the centre of each land use plot. Likewise the center of the quadrant was used as observation point for bird plot counts.

Samplings: Results included in the paper belong to the first of a four-year project in which three sampling campaigns were conducted each year for birds' monitoring, two for mollusks' monitoring and one for studying vegetation structure. The first year was unique in that all three groups were studied together.

Vegetation: We sampled vegetation quadrants of ca. $20 \times 20 \mathrm{~m}\left(400 \mathrm{~m}^{2}\right)$ (Fig. 2) according to the criteria of Chipley, Wallace \& Naranjo (2003). On the sampled quadrants we identified and counted all trees present. We considered a tree a plant with over $10 \mathrm{~cm}$ DBH $(1,10 \mathrm{~m})$. For identification we used MOGOT (n.d), Poveda and Sánchez-Vindas (1999) and Salas (1993). In the case of trees emphasis was put on morphological structure rather than species composition, although we also analyzed the relationship of the latter to other variables. 


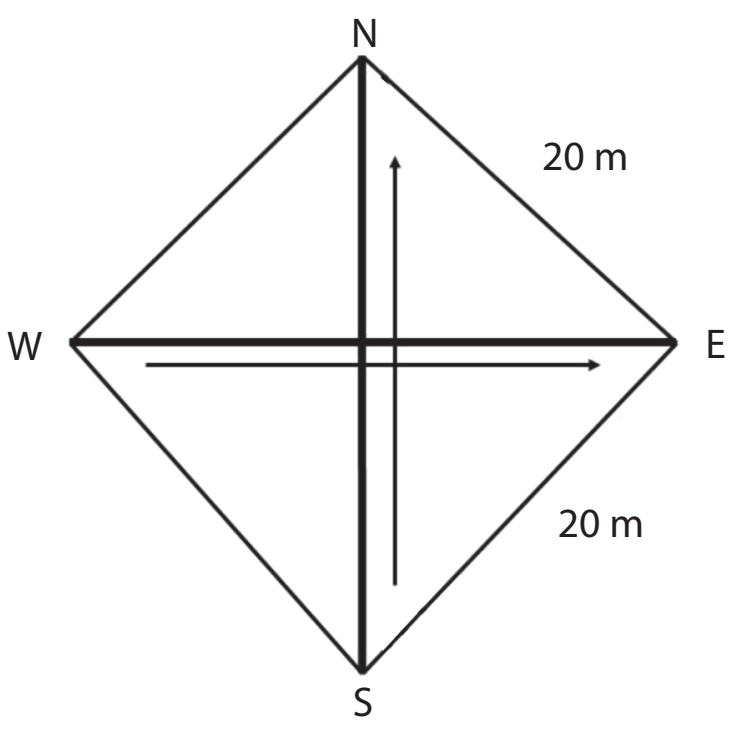

Fig. 2. Quadrant for studying vegetation structure.

Birds: We sampled birds between 6 and 10am. Observations were conducted from the chosen points within $25 \mathrm{~m}$ radio and for a period of $10 \mathrm{~min}$, on each quadrant (Wunderle, 1994), and we sampled as many plots as possible per day during the sampling campaign. For bird identification and general data on birds we utilized AOU (1998), Howell and Webb (1995), Stiles and Skutch (1998) and Martínez (2000). Bird plots were sampled three times along the year, once between March and May 2004, the second time between July and September of the same year and the last time between December 2004 and February, 2005.

Mollusks: We sampled $50 \%$ of the vegetation quadrants chosen at random, making a mixed strategy of collecting freely for $20 \mathrm{~min}$, conducting eye revision of the soil litter, rocks, logs, tree trunks, etc., as well as collecting a litter sample on an area of $50 \times 50 \mathrm{~cm}$ for further revision at the laboratory. Laboratory procedures were as usual for this taxonomic group (Altonaga, 1988).

We conducted two sampling campaigns, one between March and May 2004, and the second one between July and September of the same year. For identification of material we utilized Pérez and López (2002), as well as material stored at UCACM collections (Colecciones Centro de Malacología y Diversidad Animal de la Universidad Centroamericana).

\section{Data Analysis}

Species associated with particular land-use types: We used Microsoft Excel dynamic tables to identify species unique to each land use.
Forest dependence: A niche analysis was performed utilizing forest dependence categories proposed by Stiles and Skutch (1998), which are the following:

3: $\quad$ Low forest dependence (open area species).

3-2 (2.5): Medium to low forest dependence.

2: $\quad$ Medium forest dependence (generalist species).

2-1 (1.5): Medium to high forest dependence.

1: $\quad$ High forest dependence (forest dependent species).

Beta diversity: We used EstimateS to calculate Jaccard and Morisita Horn's indexes to assess beta diversity among land-use types (Colwell, 2004). We also conducted cluster analysis using Jaccard's index and a single linkage strategy. Cluster analysis has been widely used to assess beta diversity among different ecosystems and habitats (Pérez, Vilaseca \& Zione, 1996).

Structural relationships: We calculated bivariate correlations sensu Sokal and Rohlf (1981), among Species Richness as well as Diversity of indicator taxa (Birds, Mollusks and Plants), with Diversity of the measured vegetation height profiles (here called Structural Diversity) in order to detect possible relations amongst them. For the vegetation height profiles, frequency of observer touching the tree branches and stems within each height category (while he/she was walking down the two transects South-North and West- East, shown on Fig 2 with the arms stretched out), were considered a part of the summation made for calculating Shannon-Weaver diversity index (Shannon \& Weaver, 1949). The total sum of all categories of touching frequency played the same role as the total abundance in the usual ShannonWeaver diversity procedure for calculation. Variables analyzed were: Sveg: Vegetation Species Richness, Sbirds: Bird Species Richness, Smol: Mollusks Species Richness, Dveg: Vegetation Diversity, Dbirds: Bird Diversity, Dmol: Mollusks Diversity, DStr: Structural Diversity, SCover: Soil Cover (In terms of pastures), DBush: Bush Density and THeight: Trees Height. All statistical procedures were conducted using PAST (Øyvind, Harper \& Ryan, 2008), and SPSS. Previous to correlation data were tested for normality.

General Analysis: For birds and mollusks, we grouped all yearly values into a unique one in order to have one species richness and abundance value for each land use. The spatial ordination of land uses based on species 
associated to each of them was estimated using Principal Components Analysis.

\section{RESULTS}

\section{Species associated with particular land-use types:} On the studied land uses (13) and visited farms (41), we registered a total of 212 bird species with 3,575 individuals, as well as 56 mollusk species with 6740 individuals (Table 1). The richest land use for birds was riparian forest with 74 species and the richest for mollusks was primary forest with 35 species. As for abundance, land use with the highest abundance for birds was pastures with high density of trees with 388 individuals and for mollusks was primary forest with 1693 individuals. Species richness (170) and abundance (1 896) of trees were calculated mainly as an intermediate step towards calculating vegetation structure.

Birds: Forty-five of the 212 observed bird species were found only in a single land use type (Table 2, Fig. 3). Land uses with highest number of exclusive birds were riparian forests and the primary forest of Quirragua protected area. Land uses with lowest number of exclusive species

TABLE 1

Species richness and abundance of birds and mollusks on the 12 land use in silvopastoral systems of the municipalities of Matiguás and Rio Blanco as well as Quirragua protected area indices.

\begin{tabular}{cccccccccccccc} 
Ind. & PNA & PMA & PNB & PMB & PNS & BFL & CP & SV & BR & BSI & BS & BP & BPQ \\
Sb & 68 & 59 & 62 & 52 & 33 & 59 & 60 & 59 & $\underline{74}$ & 72 & 63 & 41 & 22 \\
$\mathrm{Ab}$ & $\mathbf{3 8 8}$ & 353 & 296 & 273 & 171 & 357 & 302 & 367 & 361 & 311 & 168 & 150 & 87 \\
$\mathrm{Sm}$ & 25 & 17 & 20 & 13 & 17 & 24 & 16 & 28 & 27 & 23 & 24 & $\mathbf{3 5}$ & 23 \\
$\mathrm{Am}$ & 412 & 411 & 562 & 321 & 335 & 502 & 214 & 533 & 354 & 487 & 547 & $\mathbf{1 6 9 3}$ & 335 \\
$\mathrm{~Sv}$ & 21 & 17 & 19 & 14 & 1 & 21 & 34 & 23 & 43 & 38 & 32 & 30 & $\underline{46}$ \\
$\mathrm{Av}$ & 170 & 174 & 100 & 54 & 0 & 210 & $\mathbf{8 2 5}$ & 174 & 270 & 247 & 153 & 77 & 294 \\
\hline
\end{tabular}

Ind: Indices, Sb: Species richness birds, Sm: Species richness mollusks, Ab: Abundance birds, Am: Abundance molluks, Sv: Species richness trees, Av: Abundance trees. Land uses included natural pasture with high tree density (PNA), natural pasture with low tree density (PNB), improved pasture with high tree density (PMA), improved pasture with low tree density (PMB), pasture without trees (PNS), fodder bank (BFL), live fence (CP), successional vegetation (SV), riparian forest (BR), modified secondary forest (BSI), secondary forest (BS), primary forest (BP), and primary forest of the Quirragua protected area (BPQ=BPP).

TABLE 2

Matrix of correlation.

\begin{tabular}{|c|c|c|c|c|c|c|c|c|c|c|c|}
\hline \multirow{2}{*}{ Variables } & \multicolumn{11}{|c|}{ Variables } \\
\hline & SVeg & SBirds & SMol & DVeg. & DBirds & DMol. & DStr. & Canopy & SCover & DBush & THeight \\
\hline SVeg & 1 & & & & & & & & & & \\
\hline SBirds & $0.44, \mathrm{~ns}$ & 1 & & & & & & & & & \\
\hline SMol & $0.40, \mathrm{~ns}$ & $-0.14, \mathrm{~ns}$ & 1 & & & & & & & & \\
\hline DVeg. & $0.7\left(^{*}\right)$ & $0.007, \mathrm{~ns}$ & $0.85^{* *}$ & 1 & & & & & & & \\
\hline DBirds & $0.70(*)$ & $0.86 * *$ & $0.05, \mathrm{~ns}$ & $0.32, \mathrm{~ns}$ & 1 & & & & & & \\
\hline DMol. & $0.6, \mathrm{~ns}$ & $-0.19, \mathrm{~ns}$ & $0.78^{* *}$ & $0.75^{*}$ & $0.18, \mathrm{~ns}$ & 1 & & & & & \\
\hline DStr. & $0.87\left(^{* *}\right)$ & $0.23, \mathrm{~ns}$ & $0.65^{*}$ & $0.88^{* *}$ & $0.54, \mathrm{~ns}$ & $0.70^{* *}$ & 1 & & & & \\
\hline Canopy & $0.87^{(* *)}$ & $0.28, \mathrm{~ns}$ & $0.57, \mathrm{~ns}$ & $0.77^{* *}$ & $0.61^{*}$ & $0.63^{*}$ & $0.93^{* *}$ & 1 & & & \\
\hline SCover & $-0.69\left(^{*}\right)$ & $0.03, \mathrm{~ns}$ & $-0.71^{*}$ & $0.87^{* *}$ & $-0.23, \mathrm{~ns}$ & $-0.75^{* *}$ & $-0.82^{* *}$ & $-0.68^{*}$ & 1 & & \\
\hline DBush & $0.51, \mathrm{~ns}$ & $-0.11, \mathrm{~ns}$ & $0.01, \mathrm{~ns}$ & $0.28, \mathrm{~ns}$ & $0.06, \mathrm{~ns}$ & $0.29, \mathrm{~ns}$ & $0.56, \mathrm{~ns}$ & $0.41, \mathrm{~ns}$ & $-0.49, \mathrm{~ns}$ & 1 & \\
\hline THeight & $0.73(*)$ & $-0.18, \mathrm{~ns}$ & $0.53, \mathrm{~ns}$ & $0.79 * *$ & 0.24 , ns & $0.76^{* *}$ & $0.83^{* *}$ & $0.84^{* *}$ & $-0.73^{*}$ & $0.53, \mathrm{~ns}$ & 1 \\
\hline
\end{tabular}

Abbreviations are: Sveg: Vegetation Species Richness, Sbirds: Bird Species Richness, Smol: Mollusks Species Richness, Dveg: Vegetation Diversity, Dbirds: Birds Diversity, Dmol: Mollusks Diversity, DStr. Structural Diversity, SCover: Soil Cover, DBush: Bush Density and THeight: Trees Height. 


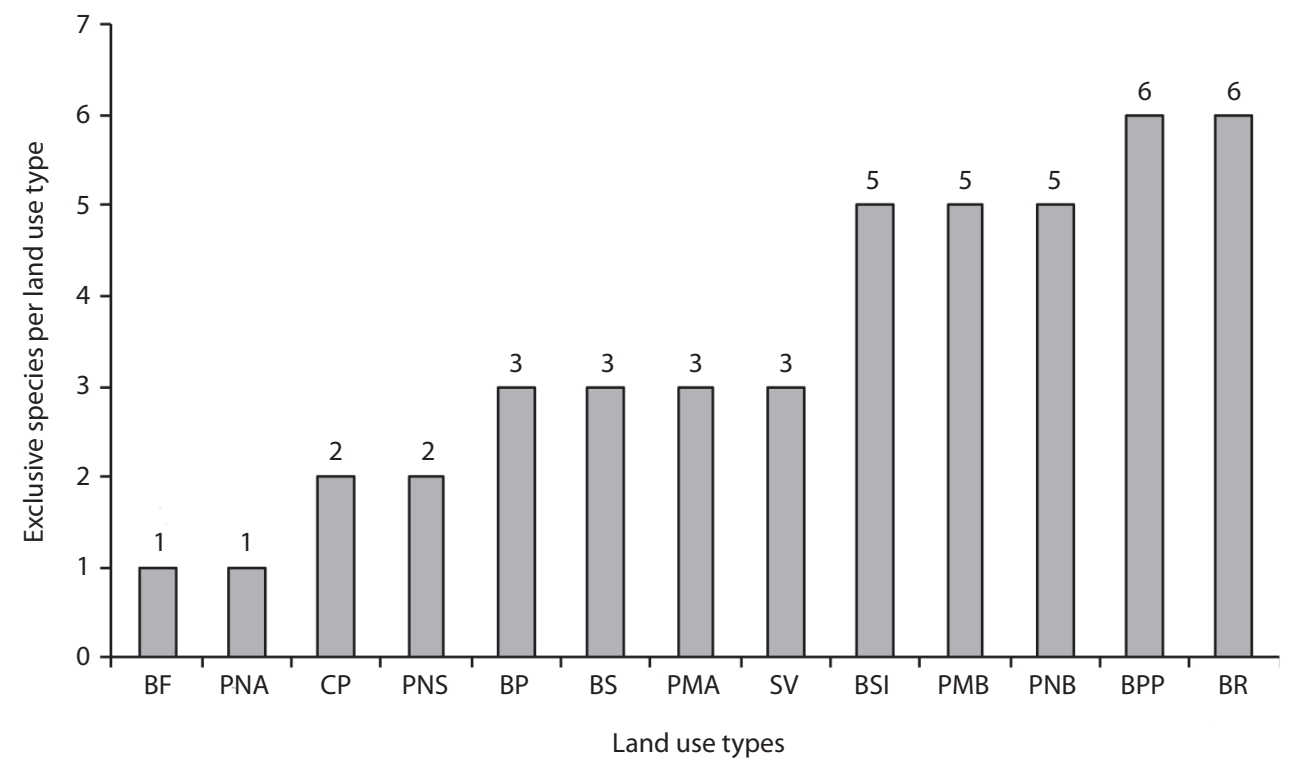

Fig. 3. Bird species associated to one of the studied land-use types. Land uses included natural pasture with high tree density (PNA), natural pasture with low tree density (PNB), improved pasture with high tree density (PMA), improved pasture with low tree density $(P M B)$, pasture without trees (PNS), fodder bank (BFL), live fence (CP), successional vegetation (SV), riparian forest (BR), modified secondary forest $(\mathrm{BSI})$, secondary forest $(\mathrm{BS})$, primary forest $(\mathrm{BP})$, and primary forest of the Quirragua protected area (BPQ=BPP).

were fodder banks and natural pastures with low density of trees, both with one exclusive species respectively.

Mollusks. Sixteen of the 56 observed mollusk species were found only within a single land use type (Table 2, Fig. 4). Land uses with highest number of unique mollusk species were the primary forest of Quirragua protected area with seven species, followed by primary forests with three species. On secondary modified forests and pastures of all kinds, there were not found exclusive species of mollusks. In the case of the silvopastoral systems studied we observed a different behavior of species diversity in relation to what we observed in previous samplings conducted on protected areas and spot forest patches on the Pacific slope (Pérez, Sotelo, Arana \& López, 2008), where secondary forests are more diverse than primary ones. We presume that, since birds followed the mentioned pattern of diversity mollusks are probably affected by soil compacted by cattle grazing.

\section{Forest dependence}

Birds: We characterized the degree of forest dependence of the observed bird species based on the classifications proposed by Stiles \& Skutch (1998). Information gathered was synthesized into three major categories of forest dependence: forest dependent species (1 and 1, 2), labeled with letter $B$, generalist species (2): $G$, and openareas species (2, 3 and 3), labeled AA.

There were observed 26 forest dependent species $(12,3 \%), 119$ generalist species making up $56,13 \%$ of the total and 67 open-areas species, composing 31,6\% of the total. These figures represent a valuable contribution to the policy and decision making process, at the local and national level, and depending on which species even at a regional (Central American) level.

Mollusks: For mollusks, we conducted the same analysis utilizing forest dependence categories proposed by Stiles \& Skutch (1998). Following these criteria we found 33 forest dependent species comprising $59 \%$ of the total, 20 generalist species representing $35,7 \%$ of the species present and three (3) open areas species. As it can be noticed, the number of species associated to forests is very high within this group, suggesting it's a good indicator of forest conservation. There is also an important number of generalist species, and a small number of species not related to forest type land uses.

\section{$\beta$ Diversity or heterogeneity among land-use types}

Birds: Values of calculated indices (Fig. 5) show medium level of similarity, in a scale ranging from 0 to 1 , 


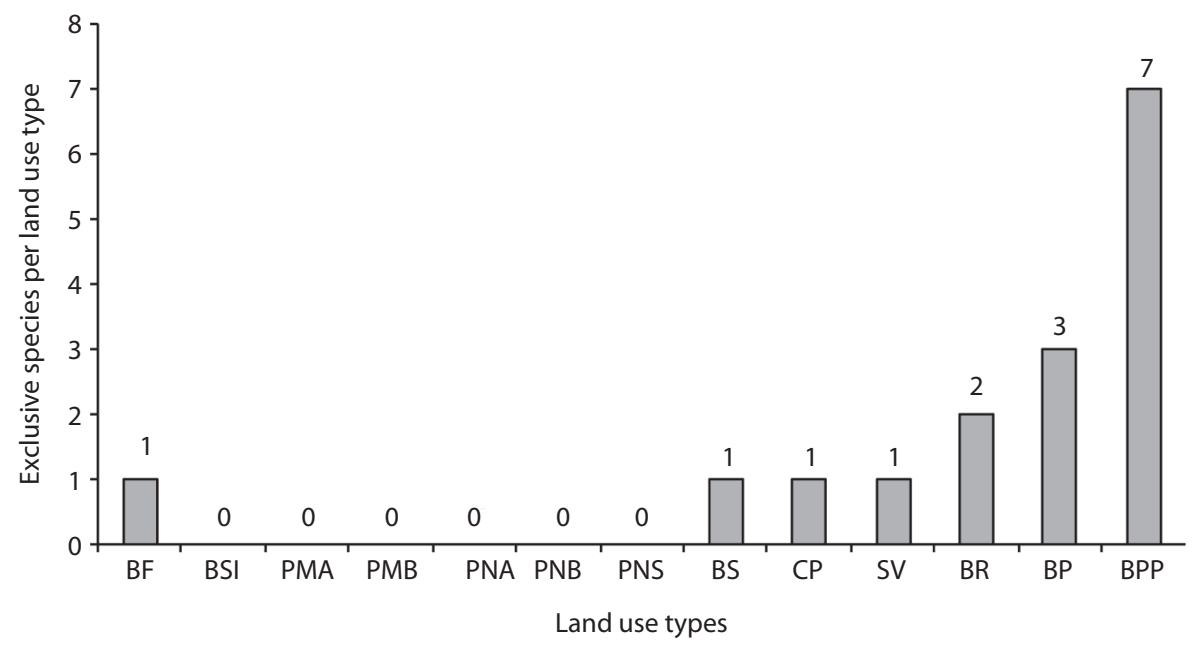

Fig. 4. Species of mollusks exclusively associated to one of the studied land-use types. Land uses included natural pasture with high tree density (PNA), natural pasture with low tree density (PNB), improved pasture with high tree density (PMA), improved pasture with low tree density (PMB), pasture without trees (PNS), fodder bank (BFL), live fence (CP), successional vegetation (SV), riparian forest (BR), modified secondary forest (BSI), secondary forest (BS), primary forest (BP), and primary forest of the Quirragua protected area $(\mathrm{BPQ}=\mathrm{BPP})$.

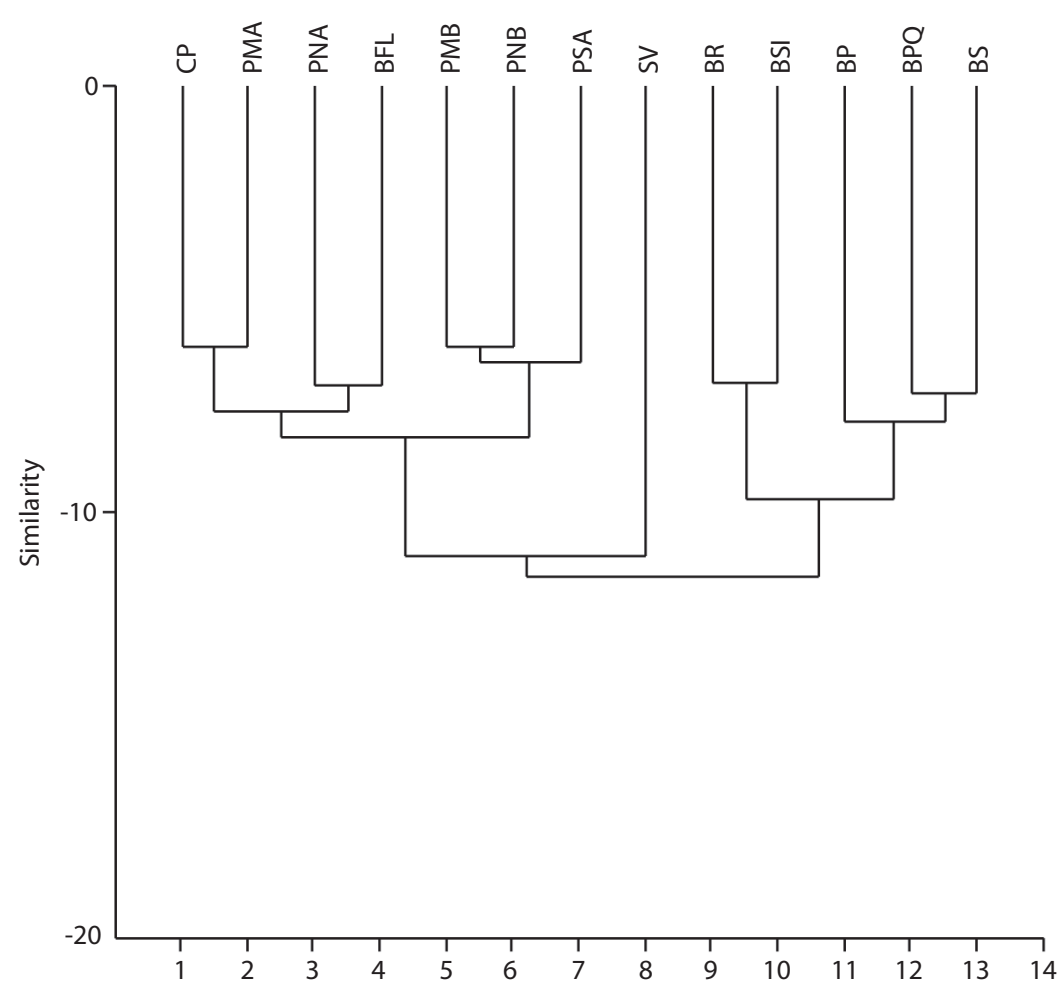

Fig. 5. Cluster analysis among land-use types considering presence and absence of bird species. 
thus Beta diversity could be as well considered medium (Morisita/Horn Average $=0,51$; Jaccard Average $=0,43$ ). It means that there are some species exclusive to particular land use types but many species are shared among various land uses, given as a result a medium turnover rate.

The above statement can be better visualized with the cluster analysis made among land uses, based on Jaccard similarity index. Cluster obtained shows the formation of two major groups, one composed of species from primary forest of Quirragua protected area and other composed of all other land use types. In the latter group it can be seen the existence of three subgroups; one composed of all forest land uses and improved pastures with low density of trees, another formed by pastures with no trees, and a third one composed of pastures, fodder banks, successions and live fences.

Mollusks: In the case of mollusks, similarity amongst land uses is lower, thus Beta diversity is a bit higher (Morisita/Horn Average $=0,6$; Jaccard Average $=0,43$ ), but could be as well considered medium. Cluster analysis performed using Jaccard similarity index (Fig. 6) also shows, as in the case of birds, the formation of two major groups, one composed of species from primary forest of Quirragua protected area and other composed of all other land use types. Within the second group there are two more or less well defined ones, one of them composed of secondary modified forests (BSI), pastures (PMB, $\mathrm{PNA}$ ) and live fences and another comprising the remaining land use types.

Structural relationships: Values for structural diversity of vegetation, (ecological) diversity and species richness were calculated for each of the three taxonomic groups studied and for each of the sampled land uses. The outcomes of the Pearson's correlation made are shown in Table 2 and Appendix 3.

Results indicate the existence of a significant correlation between Vegetation Species Richness and Bird Diversity $(r=0,7, p<0,05)$, however the relation between Bird Diversity and Vegetation Diversity, as well as Bird Diversity and Structural Diversity were not significant; the former probably because of the low abundance exhibited by many tree species and the latter probably due to the existence of various pasture land uses with low Structural Diversity values as it is expected.

On the other hand, it was observed a very significant correlation between species richness of vegetation and structural diversity $(r=0,874, p<0,01)$ and between species richness of vegetation and canopy cover $(r=0,866$,

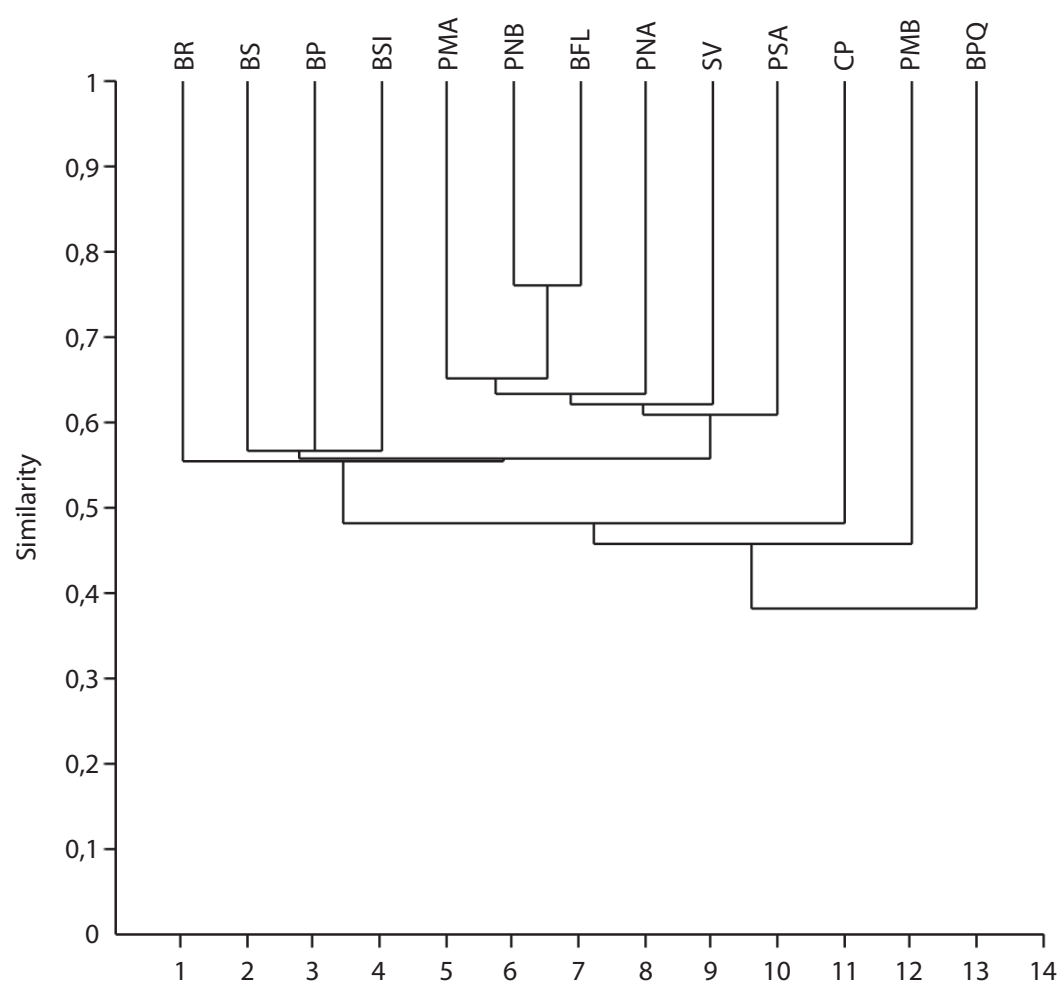

Fig. 6. Cluster analysis among land-use types considering presence and absence of mollusks species. 
$p<0,01)$, increasing both structural diversity and canopy cover with the increase on species richness of vegetation, also as expected.

Another remarkable aspect was finding a very significant relationship between diversity of vegetation and diversity of mollusks $(r=0,751, p<0,05)$, which is probably more related to leaf litter production than to diversity of vegetation itself, as pointed out by Pérez et al., (2008).

General analysis: As it is observed on the PCA based on species richness amongst land use types, and considering all three groups together (Fig. 7), there is a trend towards the formation of two groups, one encompassing all forest land uses (BSI, SV, BR, BS, BP and CP) with the exception of the primary forest of Quirragua Protected Area, which is separated from all other land uses.

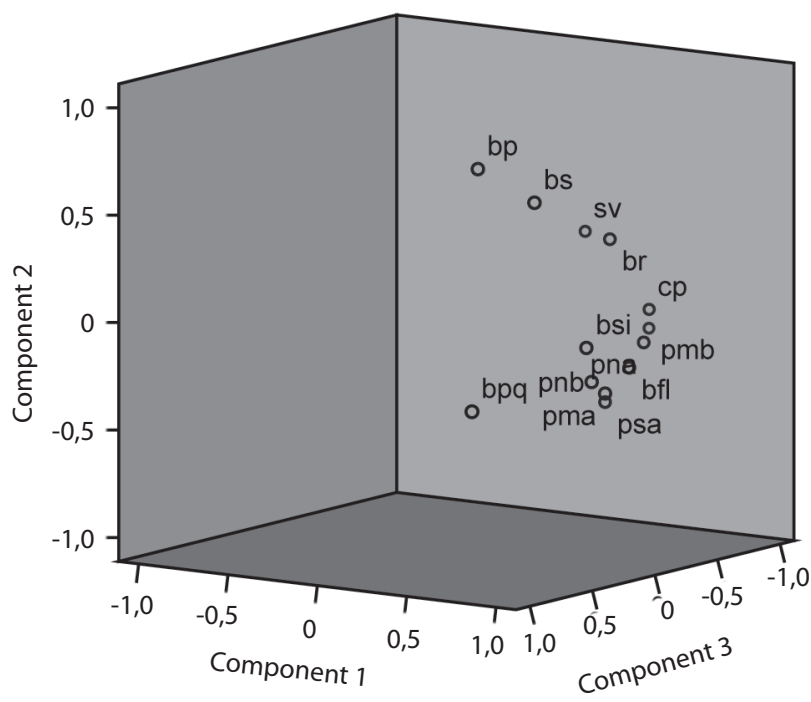

Fig. 7. Principal Component Analysis among land use types considering species abundances of all three taxa under study. Components 1, 2 and 3.

\section{DISCUSSION}

Species associated with particular land-use types: The identification of valid indicator species for revealing conservation or degradation of animal and plant communities has long constituted an important research topic on community ecology. Indicator species are valuable for monitoring the status of ecological communities without needing to assess the entire species ensemble (Noss, 1990; Spellerberg \& Sawyer, 1999).

Another subject on debate is which taxon is best as bio-indicator. Most authors hold results supporting their own taxa of interest as best for a monitoring strategy (Pérez, 2004), and that is because in all taxa there are species whose presence or absence, or even its abundance fluctuations provide information on health of a habitat or ecosystem.

Peris and Masa (1992) and Chipley et al. (2003), amongst other authors, point out that birds are among the best indicators and our results confirm such statement. In this paper we present some bird species strictly associated to forest land uses, as well as some species strictly associated to pastures.

For mollusks there was data already available for the Nicaraguan Pacific Slope supporting its condition of good indicators (Pérez \& López, 2002; Pérez et al., 2008), however there was insufficient data available for the region under study, the North-Central region of the country, so the results presented in this paper are the first to northern Nicaragua.

For birds as well as for mollusks there were found some species unique to each land use type as it was mentioned, being primary forests the type of land use with highest amount of exclusive species associated to it. However, as mentioned by Pérez et al. (2004a, 2006), in many occasions secondary forests constitute land use types or ecosystems more diverse than primary forests, since they keep some components of the primary forest biota and incorporate some alien components through the anthropization process, such as man-made borders and gaps created for agricultural purposes. Nevertheless, it should be pointed out that some pristine forest components are lost in this process (MacArthur \& MacArthur, 1961; Odum, 1986).

Beta diversity: According to Magurran (1987), beta diversity is an expression of the degree of partition of the environment into patches or biological mosaics in relation to some kind of gradient, being this altitudinal or longitudinal. In relation to the former may be mentioned the contributions of Kikkawa and Williams (1971) on birds of New Guinea, as well as Terborgh's (1977) on Andean birds. Regarding mollusks should be cited the paper by Burla and Stahel (1983), on populations of the snail Arianta arbostorum of the Alps, and the work of Pérez, Arana, Sotelo and Bonilla (2004b) on land snail communities of Maderas hill at Ometepe Island, Nicaragua, among others. Regarding vegetation should be mentioned the paper by Gillespie and Prigge (1977), on altitudinal analysis of vegetation at Concepción Volcano, Ometepe Island, Nicaragua.

As for longitudinal or landscape beta diversity, Sáenz and Montero (2006) stated that high beta diversity could 
increase instability of taxonomic ensembles, thus the values obtained by us might be guarantee to taxonomic stability of the studied landscape.

One important aspect pointed out by Vílchez et al. (2008) on their study of Nicaraguan birds, is that atypical similarities observed among some land uses, as riparian forest with pastures, are probably explained by the species they share due to the arrangement of land uses within the landscape matrix, where some land uses are adjacent to others, instead of an actual similarity among them. Up to the present we had not found specific references about community structure of terrestrial mollusks on silvopastoral systems.

Structural relationships: One aspect to point out is that with increasing Vegetation Species Richness, a very significant decrease in Soil Cover (in terms of pastures) is observed $(r=-0,70, p<0,05)$. This aspect is often noted by local farmers and can be corrected by using improved pastures (E. Ramírez, Per. Com.), which adapt well to shadow conditions caused by tree canopy.

Regarding birds, results indicate the existence of a significant correlation between Vegetation Species Richness and Bird Diversity $(r=0,7, p<0,05)$, however the relation between Bird Diversity and Vegetation Diversity, as well as Bird Diversity and Bird Species Richness to Structural Diversity were not significant as found by MacArthur and MacArthur (1961), and more recently by Lang et al. (2003).

Some remarkable results were obtained for mollusks. It was found that for this group Species Richness and Diversity showed a significant and a very significant relationship, respectively, with Structural Diversity $(r=0,655$, $p<0,05, r=0,7, p<0,01)$, and also a significant and a very significant relationship between Species Richness and Diversity, respectively, with Vegetation Diversity $(r=0,85$, $p<0,01 ; r=0,75, p<0,05)$.

Furthermore, Mollusks Species Diversity showed a significant relationship with Canopy Cover $(r=0,63, p<$ $0,05)$, which might be explained by the fact that these variables are related to litter production, and the latter constitutes a key element to the habitats of land snails (Pérez et al., 2008).

General Analysis: According to various authors Principal Components Analysis (PCA) is the most straightforward way to ordinate data (Reyment, Blackith \& Campbell, 1984; Ludwig \& Reynolds, 1988; Gotelli \& Ellison, 2004). On the PCA we observed a trend to the clustering of forest uses on one hand (BP, BR, BS, etc) and pasture uses on the other hand. The primary forest of Quirragua protected area separates from the rest. The distance between Quirragua protected area and all other land uses studied might be due to the presence of some altitude-related species that do not occur at silvopastoral systems located at the plains. The three components plotted accounted for more than $85 \%$ of the total variance.

\section{CONCLUSIONS}

1. Our study shows that silvopastoral systems and in general agricultural landscapes contain highly diverse communities of animals and plants that should be managed properly on the landscape context in order to create a matrix where conservation and production can take place at the same time and have the potential to be incorporated into biodiversity conservation plans.

2. Diversity and Species Richness of birds and mollusks show a significant relationship to Structure of Vegetation on different land uses studied (Table 2), as found by other authors.

3. Land-uses exhibit an important number of species strictly associated to them, 45 out of 212 for birds (Appendix 1) and 16 out of 56 for mollusks (Appendix 2). These species are considered crucial for management purposes. Land uses with highest number of exclusive birds are riparian forests and primary forest of Quirragua protected area with six species; land use with highest number of mollusk species is primary forest of Quirragua protected area with seven species.

4. Analyzing the results of our project we detected some land uses that deserve some kind of protection due to either its species richness or its species abundance (Table 1). Since protected areas at the national level might constitute a burden for the National System of Protected Areas' budget, may be they could constitute either Ecological Parks or Private Reserves.

\section{ACKNOWLEDGEMENTS}

The basic information for this paper was gathered during the first of a four-year project funded by $A B C$ and The World Bank, as well as some general analyses supported by The Netherlands Agency for Environmental Assessment (PBL) from the Netherlands, during the last year of the project. We are grateful to Robert Chipley and George Wallace, from $A B C$, USA, for the support given 
during the years the project took place, as well as to Tonnie Tekelenburg from PBL, The Netherlands. We are also thankful to Elías Ramírez from NITLAPAN Institute, for his collaboration during the development of the project.

Last but not least, we are grateful to eff Milder, Department of Natural Resources, Cornell University and José M. Zolotoff, Fundación Cocibolca, Nicaragua, for their critical reading and corrections made to the manuscript.

\section{REFERENCES}

Agostini, P., Ibrahim, M., Murgueitio, E., \& Ramirez, E. (2003). Manual operativo del proyecto "Enfoques Silvopastoriles Integrados para el Manejo de Ecosistemas". Turrialba, Costa Rica. Retrieved from http://www.rlc.fao.org/foro/ psa/pdf/enfoque.pdf

Altonaga, K. (1988). Estudio taxonómico y biogeográfico de las familias Endodontidae, Euconulidae, Zonitidae y Vitrinidae (Gastropoda: Pulmonata: Stylommatophora) de la península ibérica, con especial referencia al País Vasco y zonas adyacentes. (Tesis Doctoral inédita). Universidad del País Vasco.

AOU. (1998). Check-list of north american birds. 7ma ed., Allen Press.

Bergin, T.M., Best, L.B., Freemark, K.E., \& Koehler, K.J. (2000). Effects on landscape structure on nest predation in roadsides of a midwestern agroecosystem: a multiscale analysis. Landscape Ecology, 15, 131-143.

Burla, H. \& Stahel, W. (1983). Altitudinal variation in Arianta arbostorum (Mollusca, Pulmonata) in the Swiss Alps. Genetica, 62, 95108.

Cárdenas, G., Harvey, C., Ibrahim, M. \& Finnegan, B. (2003). Diversidad y riqueza de aves en diferentes hábitats en un paisaje fragmentado en Cañas, Costa Rica. Agroforestería en las américas, 10(39-40), 78-85.

CBM-MARENA. (2001). Información CBM Nicaragua. MARENASICA/CCAD-PNUD/GEF-GTZ-PNUMA-BANCO MUNDIAL. Managua. En soporte CD.

Chipley, R., Wallace, G. \& Naranjo, L. (2003). Manual para el Monitoreo de Biodiversidad. Unpublished. American Bird Conservancy, Washington DC. 42 p.

Colwell, R. K. (2004). EstimateS, Version 7: Statistical Estimation of Species Richness and Shared Species from Samples

Estrada, A. \& Coates-Estrada, R. (2002). Dung beetles in continuous forest, forest fragments and in an agricultural mosaic habitat island at Los Tuxlas, Mexico. Biodiversity and conservation, 11, 1903-1918.

Fournier, E. \& Loreau, M. (2001). Respective roles of recent edges and forest patch remnants in the maintenance of ground-beetle (Coleoptera: Carabidae) diversity in an agricultural landscape. Landscape ecology, 16, 17-32.
Gillespie, T. W. \& Prigge, B. (1997). Flora and vegetation of a primary succesional community along an altitudinal gradient in Nicaragua. Brenesia, 47-48, 73-82.

González-Valdivia, N., Ochoa-Gaona, S., Pozo, C., Ferguson, B.G., Rangel-Ruiz, L.J. Arriaga-Weiss, S.L., Ponce-Mendoza, A. and Kampichler, C. 2011. Indicadores ecológicos de hábitat y biodiversidad en un paisaje neotropical: perspectiva multitaxonómica Rev. Biol. Trop. Vol. 59 (3): 1433-1451.

Gotelli, N.J. and Ellison, A.M. 2004. A primer of ecological statistics. Sinauer, Massachussets. 510 p.

Guinea. Search (Sydney), 2, 64-65.

Harris, L.D. (1984). The fragmented forest. Island biogeographic theory and the preservastion of biotic diversity. Chicago, Illinois, USA: University of Chicago Press.

Hernández, B., Maes, J.M., Harvey, C., Vílchez, S., Medina, A. \& Sánchez, D. (2003). Abundancia y diversidad de escarabajos coprófagos y mariposas diurnas en un paisaje ganadero en el departamento de Rivas, Nicaragua. Agroforestería en las américas, 10(39-40), 93-102.

Howell, S. \& Webb, S. (1995). A guide to the birds of México and Northern Central América. Oxford University press Inc. New York, USA. 851 p.

INAFOR (Instituto Nacional Forestal). (2009). Resultados del inventario forestal nacional 2008-2009. INAFOR, Managua. $231 \mathrm{p}$.

INEC (Instituto Nacional de Estadísticas y Censos). (1995). Censos Nacionales. Cifras oficiales finales. INEC, Managua. 46 p.

INIFOM. (2004). Caracterizaciones. Retrieved 12.2004 from http::// www.inifom.gob.ni/

Jeanneret, P., Schüpbach, B., Pfiffner, L. \& Walter, T. (2003). Arthropod reaction to landscape changes and avian features in agricultural landscapes. Landscape ecology, $18,253-263$

Kessler, M., Herzog, S.K., Fjeld, S.A. \& Back, K. (2001). Species richness and endemism of plant and bird communities along two gradients of elevation, humidity and landuse on the Bolivian Andes. Biodiversity and distributions, 7,61-77.

Kikkawa, J. \& Williams, W.T. (1971). Altitudinal distribution of land birds in New

Lang, I., Lorraine, H.L.G., Harvey, C. \& Sinclair, F.L. (2003). Composición de la comunidad de aves en cercas vivas del Río Frío, Costa Rica. Agroforestería en las américas, 10(39-40), 86-92.

Lawton, J.H., Bignell, D.E., Bolton, B., Bloemers, G.F., Eggleton, P., Hammond, M. odda, P.M., Holt, R.D., Larsen, T.B., Mawsdley, N.A., Stork, N.E., Srivastava, S. \& Watt, A.D. 1998. Biodiversity inventories, indicator taxa and effects of habitat modification in tropical forest. Nature, 391, 72-76. 
Levard, L., Marín, Y., \& Navarro, I. (2001). Municipio de Matiguás, potenciales y limitantes del desarrollo agropecuario. Cuaderno de Investigación, 11. Managua, Nicaragua: Universidad Centroamericana.

López, M., Gómez, R., Harvey, C. \& Villanueva, C. (2004). Caracterización del componente arbóreo en los sistemas ganaderos de Rivas, Nicaragua. Encuentro, 68, 114-133.

Ludwig, J.A. \& Reynolds, J.F. (1988). Statistical Ecology. A primer on methods and computing. John Wiley \& Sons, USA. 337 p.

Luna, G. (2005). Comunidades de hormigas en agroecosistemas de la RAAS, Nicaragua.Tesis de Licenciatura, UCA. Managua. $176 \mathrm{p}$.

MacArthur, R.H. \& MacArthur, J.W. (1961). On bird species diversity. Ecology, 42, 594-598.

Magurran, A.E. (1987). Ecological diversity and its measurement. Princeton University Press, Princeton. 177 p.

MARENA. (2004). Indicadores ambientales de Nicaragua. Volumen I. Managua, Nicaragua: Impresión comercial La Prensa.

Martínez, J.C. (2000). Lista patrón de las aves de Nicaragua. National Fish and Wildlife Foundation-Fundación Cocibolca-GTZ, Managua. 59 p.

Medina, A., Harvey, C., Vílchez, S., Sánchez, D. \& Hernández, B. (2004). Diversidad y composición de Chiropteros en un paisaje fragmentado de bosque seco en Rivas, Nicaragua. Encuentro, 68, 24-43.

MOGOT (n.d.). Retrieved 12.2004 from www.mogot.org.

Naranjo, L.G. (2004). Wild birds in Latin American pasture lands. Retrieved 12.2004 from http://www.virtualcentre.org.

Noss, R. (1990). Indicators for monitoring biodiversity. A hierachical approach, Conservation Biology, 4, 355-364

Odum, E.P. (1986). Fundamentos de ecología. Interamericana, México, DF. 422 p.

Øyvind, H., Harper, D.A.T. \& Ryan, P.D. (2008). PAST PAlaeontological STatistics, ver. 1.79. User's Manual. 87 p.

Pérez, A.M. \& López, A. (2002). Atlas de los moluscos continentales del Pacífico de Nicaragua. Editorial UCA, Managua. $312 \mathrm{p}$.

Pérez, A.M. (2004). Aspectos conceptuales, análisis numérico, monitoreo y publicación de datos sobre biodiversidad. Araucaria-Marena, Managua. 300 p.

Pérez, A.M., Arana, I., Sotelo, M. \& Bonilla, B. (2004b). Altitudinal variation of diversity on landsnail communities from Maderas Volcano, Ometepe, Nicaragua Iberus, 22(1), 133-145.

Pérez, A.M., Bornemann, G., Campo, L., Arana, I., Sotelo, M., Ramírez, F. \& Castañeda, E. (2004a). Biodiversidad y producción en sistemas silvo-pastoriles. Cuadernos de Investigación UCA, 15, 1-77.
Pérez, A.M., Sotelo, M., Arana, I. \& López, A. (2008). Diversidad y aspectos del hábitat en las comunidades de moluscos gasterópodos terrestres en la región del Pacífico de Nicaragua. Rev. Biol. Trop. 56(1), 317-333.

Pérez, A.M., Sotelo, M., Ramírez, F., Ramírez, I., López, A. \& Siria, I. (2006). Conservación de la biodiversidad en sistemas silvopastoriles de Matiguás y Rio Blanco, Dpto de Matagalpa, Nicaragua. Ecosistemas, 2006/3.

Pérez, A.M., Vilaseca, J.C. \& Zione, N. 1996. Sinecología básica de moluscos terrestres en cuatro formaciones vegetales de Cuba. Rev. Biol. Trop., 44(1), 133-146.

Pérez, AM. (2002). Redes ecológicas: un uso alternativo del término y su aplicación a la conservación de la diversidad in situ. Un enfoque preliminar. Gaia, 2: 1-10.

Peris, S.J. \& Masa, A.I. (1992). Comunidades nidificantes y invernantes de aves del encinar adehesado (Quercus rotundifolia) del centro-oeste de la Península Ibérica. Airo, $3(3), 75-82$.

Petit, S. \& Usher, M.B. (1998). Biodiversity in agricultural landscapes: the ground beetle communities of woody uncultivated habitats. Biodiversity and conservation, 7, 1549-1561.

Poveda, I. \& Sánchez-Vindas, P. (1999). Arboles y palmas del Pacífico Norte de Costa Rica. Claves dendrológicas. Editorial Guayacán, Heredia, Costa Rica. 186 p.

Regos, J. (1989). Introducción a la ecología tropical. Editorial UCA, Managua. $252 \mathrm{p}$.

Reyment, R.A., Blackith, R.E. \& Campbell, N.A. (1984). Multivariate morphometrics. Academic Press, London. 233 p.

Ricketts, T.H., Daily, G.C., Ehrlich, P.R. \& Pay, J.P. (2001). Countryside biogeography of moths in a fragmented landscape: biodiversity in native and agricultural habitats. Conservation biology, 15(2), 378-388.

Ruíz, A. (2003). Sistemas silvopastoriles: una alternativa de servicios ambientales y mejorar el nivel de vida de las familias ganaderas en Nicaragua. Managua, Nicaragua: IMPRIMATUR.

Sáenz, J.C \& Montero, J. (2006). Gradientes de diversidad en los Agropaisajes del Neotrópico: Una propuesta para determinar el umbral de la biodiversidad. PP presentation.

Salas, J. (1993). Arboles de Nicaragua. IRENA, Managua. 390 p.

Sánchez, D., López, M., Medina, A., Gómez, R., Harvey, C., Vílchez, S., Hernández, B., López, F., Joya, M., Sinclair, F.L. \& Kunth, S. (2004). Importancia ecológica y socioeconómica de la cobertura arbórea en un paisaje fragmentado de bosque seco de Belén, Rivas, Nicaragua. Encuentro, 68, 7-23.

Schulze, C.H., Waltert, M., Kessler, P.J.A., Pitopang, R.S., Veddeler, D., Mühlenberg, M., Gradstein, S.R., Leuschner, C., Steffan-Dewenter, I. \& Tscharntke, T. (2004). Biodiversity indicator groups of tropical land-use systems: comparing plants, birds and insects. Ecological applications, 14(5), 1321-1333. 
Shannon, C.E. \& Weaver, W. (1949). The mathematical theory of comunication. University Illinois Press, Urbana, Illinois.

Sokal, R.R. \& Rolhf, F.J. (1981). The principles and practice of statistics in Biological research. State University of New York at Stony Brook. 859 p.

Spellerberg, I.F. \& Sawyer, J.W.D. (1999). An introduction to applied biogeography. Cambridge University Press, Cambridge. 243 p.

Stiles, F. \& Skutch, A. (1998). Guía de Aves de Costa Rica. $2^{\mathrm{a}}$ ed. INBIO, Heredia, Costa Rica. 702 p.

Terborgh, J. (1977). Bird species diversity on an Andean elevational gradient. Ecology, 58, 1007-1019.

Vílchez, S., Harvey, C., Sánchez, D., Medina, A. \& Hernández, B. (2004). Diversidad de aves en un paisaje fragmentado. Encuentro, 68, 60-75.

Vílchez, S., Harvey, C., Sánchez, D., Medina, A., Hernández, B \& Taylor, R. (2008). Diversidad de aves en un agropaisaje de Nicaragua. In: Evaluación y conservación de biodiversidad en paisajes fragmentados de Mesoamérica. Harvey, C. and Sáenz, J. Eds., 547-676.
Villanueva, C., Ibrahim, M., Harvey, C. \& Esquivel, H. (2003). Tipología de fincas con ganadería bovina y cobertura arbórea en pasturas en el trópico seco de Costa Rica. Agroforestería en las Américas, 10(39-40), 9-16.

Weibull, A.C., Ostman, O. \& Granquist, A. (2003). Species richness in agroecosystems: the effect of landscape, habitat and farm management. Biodiversity and conservation, $12,1335-1355$.

Wilcox, B.A. (1980). Insular ecology and conservation. In Soulé, M.E., \& Wilcox, B.A.(eds), pp. 95-117. Conservation biology an evolutionary-ecological perspective. Sunderland, Massachussets, USA: Sinauer Associates, Inc., Publishers

Wilcox, B.A., Murphy, D.D., Ehrlich, P.R. \& Austin, G.T. (1986). Insular biogeography of the montane butterfly faunas in the Great Basin: Comparison with birds and mammals. Oecologia, 69, 188-194.

Wunderle, J.M. (1994). Métodos para contar aves terrestres del Caribe. USDA, Forest Service. General Technical Report SO100. $28 \mathrm{p}$. 
APPENDIX 1

Unique bird species and land uses.

\begin{tabular}{|c|c|c|c|c|c|c|c|c|c|c|c|c|c|}
\hline \multirow{2}{*}{ Species } & \multicolumn{13}{|c|}{ Land uses } \\
\hline & $\mathrm{BF}$ & $\mathrm{BP}$ & $\mathrm{BPQ}$ & $\mathrm{BR}$ & BS & BSI & $\mathrm{CP}$ & PMA & PMB & PNA & PNB & PNS & SV \\
\hline Aimophilia ruficauda & & & & & & & & & $x$ & & & & \\
\hline Amazona autumnalis & & & & & & & & $x$ & & & & & \\
\hline Archilocus colubris & & & & & & & $x$ & & & & & & \\
\hline Caprimulgus vociferus & & & & $x$ & & & & & & & & & \\
\hline Capsiempis flaveola & & & & $x$ & & & & & & & & & \\
\hline Caracaras plancus & & & & & & & & & & & $x$ & & \\
\hline Carduelis psaltria & & & & & & & & & $x$ & & & & \\
\hline Caryothraustes poliogaster & & & $x$ & & & & & & & & & & \\
\hline Casmerodius albus & & & & & & & & & & & & $x$ & \\
\hline Catharus aurantirostris & & & $x$ & & & & & & & & & & \\
\hline Ceryle torquata & & & & $x$ & & & & & & & & & \\
\hline Chordeiles acutipennis & & & & & & & & & $x$ & & & & \\
\hline Colinus leucopogon & & & & $x$ & & & & & & & & & \\
\hline Columbina passerina & & & & & & & & & & & $x$ & & \\
\hline Dendrocincla homochroa & & & $x$ & & & & & & & & & & \\
\hline Dendroica caerulescens & & & & & & & $\mathrm{X}$ & & & & & & \\
\hline Dendroica discolor & & & & & & & & & & & & & $\mathrm{X}$ \\
\hline Dendroica fusca & $x$ & & & & & & & & & & & & \\
\hline Dendroica magnolia & & & & $x$ & & & & & & & & & \\
\hline Dendroica towsendii & & & & & & & & & & & $x$ & & \\
\hline Egretta caerulea & & & & & & & & & & & $x$ & & \\
\hline Eugenes fulgens & & & & & & $x$ & & & & & & & \\
\hline Eumomota superciliosa & & & & & & & & & & & & & $\mathrm{X}$ \\
\hline Eupherusa eximia & & & & & $\mathrm{X}$ & & & & & & & & \\
\hline Euphonia gouldi & & & $x$ & & & & & & & & & & \\
\hline Falco rufigularis & & & & & & & & & $x$ & & & & \\
\hline Falco sparverius & & & & & & & & & & & & $x$ & \\
\hline Icterus dominicensis & & & & & $x$ & & & & & & & & \\
\hline Legatus leucophaius & & $\mathrm{X}$ & & & & & & & & & & & \\
\hline Melanerpes pucherani & & $\mathrm{X}$ & & & & & & & & & & & \\
\hline Molothrus aeneus & & & & & & & & & & & & & $\mathrm{X}$ \\
\hline Momotus momota & & & & & & $x$ & & & & & & & \\
\hline Mycteria americana & & & & & & & & & & $x$ & & & \\
\hline Myiarchus cinerascens & & & & & & $x$ & & & & & & & \\
\hline Myiopagis viridicata & & & & & & & & $x$ & & & & & \\
\hline Myiozetetes granadensis & & $\mathrm{X}$ & & & & & & & & & & & \\
\hline Myrmornis torquata & & & $x$ & & & & & & & & & & \\
\hline Ramphocelus sanguinolentus & & & & & & & & $x$ & & & & & \\
\hline Riparia riparia & & & & & & & & & $x$ & & & & \\
\hline Seiurus noveboracensis & & & & & & $x$ & & & & & & & \\
\hline Tangara lavinia & & & $\mathrm{X}$ & & & & & & & & & & \\
\hline Tolmomyias asimilis & & & & & $\mathrm{X}$ & & & & & & & & \\
\hline Tyto alba & & & & & & & & & & & $x$ & & \\
\hline Vermivora chrysoptera & & & & $x$ & & & & & & & & & \\
\hline Zimmereus vilissimus & & & & & & $x$ & & & & & & & \\
\hline Total & 1 & 3 & 6 & 6 & 3 & 5 & 2 & 3 & 5 & 1 & 5 & 2 & 3 \\
\hline
\end{tabular}


APPENDIX 2

Unique mollusk species and land uses.

\begin{tabular}{|c|c|c|c|c|c|c|c|c|c|c|c|c|c|}
\hline \multirow{2}{*}{ Species } & \multicolumn{13}{|c|}{ Land uses } \\
\hline & $\mathrm{BF}$ & $\mathrm{BP}$ & BPP & BR & BS & BSI & $\mathrm{CP}$ & PMA & PMB & PNA & PNB & PNS & SV \\
\hline Diplosolenodes occidentalis & & & & & & & $\mathrm{X}$ & & & & & & \\
\hline Helicina rostrata & & & & & & & & & & & & & $x$ \\
\hline Schasichila alata & & & $x$ & & & & & & & & & & \\
\hline Microconus wilhelmi & & & $x$ & & & & & & & & & & \\
\hline Orthalicus princeps & & & $x$ & & & & & & & & & & \\
\hline Pseudopeas sp. & & & & & $x$ & & & & & & & & \\
\hline Pseudosubulina sp. & & & $x$ & & & & & & & & & & \\
\hline Punctum burringtoni & & & $x$ & & & & & & & & & & \\
\hline Salasiella guatemalensis & $x$ & & & & & & & & & & & & \\
\hline Streptostyla turgidula & & & $x$ & & & & & & & & & & \\
\hline Striatura meridionalis & & $x$ & & & & & & & & & & & \\
\hline Strobilops strebeli guatemalensis & & & $x$ & & & & & & & & & & \\
\hline Subulina parana & & $x$ & & & & & & & & & & & \\
\hline Succinea guatemalensis & & & & $x$ & & & & & & & & & \\
\hline Thysanophora costaricensis & & $\mathrm{x}$ & & & & & & & & & & & \\
\hline Trichodiscina coactiliata & & & & $x$ & & & & & & & & & \\
\hline Total & 1 & 3 & 7 & 2 & 1 & 0 & 1 & 0 & 0 & 0 & 0 & 0 & 1 \\
\hline
\end{tabular}


APPENDIX 3

Relationships between variables of vegetation structure and species richness or diversity of vegetation, birds and mollusks.
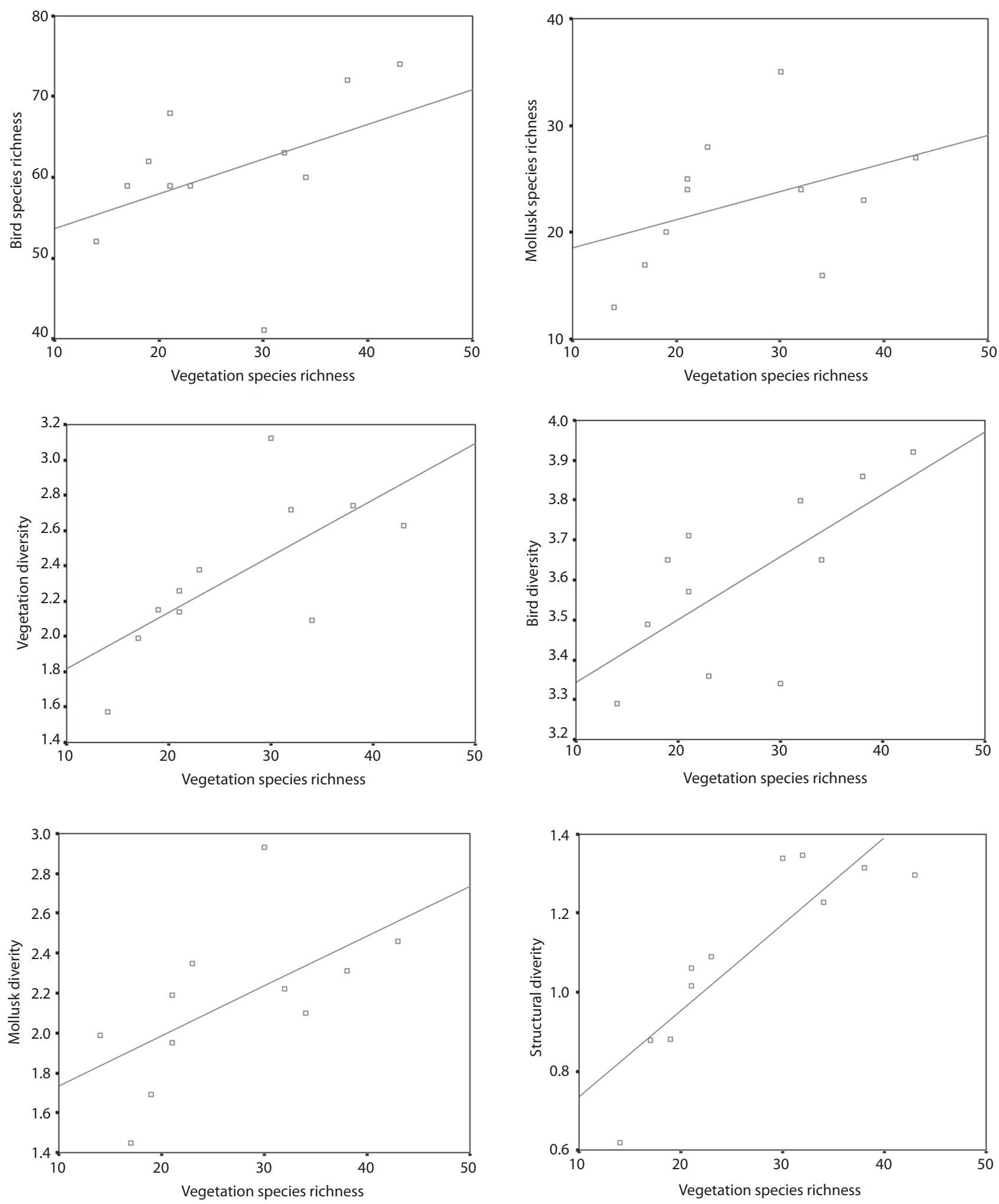
APPENDIX 3 (Continued)

Relationships between variables of vegetation structure and species richness or diversity of vegetation, birds and mollusks.
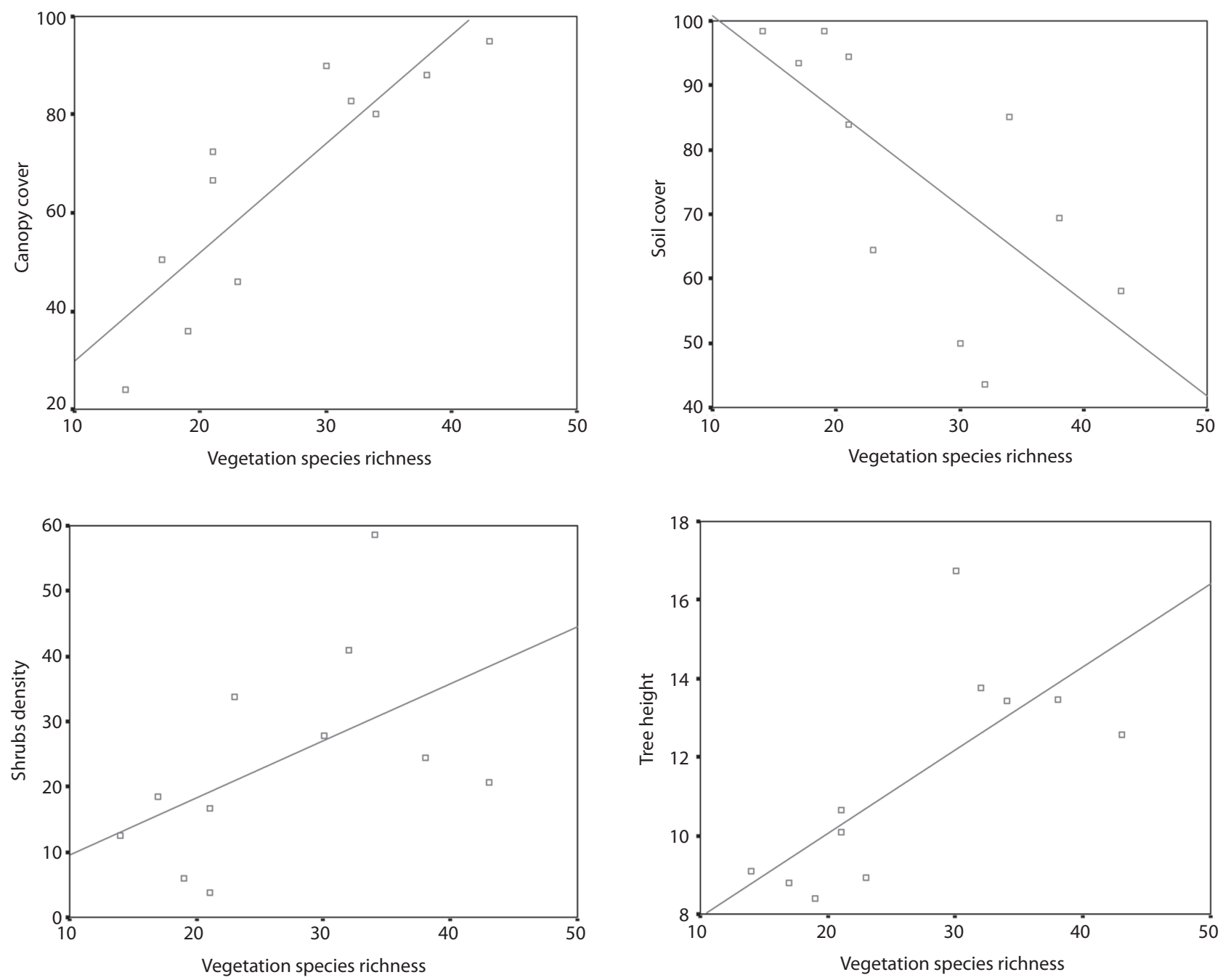
